\title{
Civil War from a Transnational Perspective
}

Kristian Skrede Gleditsch, University of Essex \& Peace Research Institute Oslo (PRIO)

Summary: Civil war is the dominant form of armed conflict in the contemporary international system, and most severe lethal armed conflicts in the post-Cold War era have been civil rather than interstate. Still, it would misleading to see these conflicts as purely domestic, as many contemporary civil wars such as Syria display clear transnational characteristics, including inspirations from events in other countries, links to actors in other countries, as well as often international interventions. Moreover, civil wars often have important implications for other states, including security concerns and economic impacts. This chapter reviews the growth and core findings in the literature focusing on the transnational dimensions of civil war. I focus in particular on how factors outside a particular state can influence the risk of conflict within states as well as some of the central consequences of domestic conflict for other states or relations between states. I conclude that this line of research has helped expand our understanding of both civil conflict and interstate war, and that a comparative focus on varieties conflict and attention to the possible transnational dimensions of civil war deserve a prominent role in future research.

Keywords: civil war, interstate disputes, transnational actors, diffusion, conflict spillovers 
Acknowledgements: I would like to acknowledge helpful discussions with Baris Ari, Lars-Erik Cederman, David Cunningham, Nils Petter Gleditsch, Sara Polo, Marc Lynch, Idean Salehyan, Håvard Strand, and Andrea Ruggeri. 


\section{Introduction}

Civil war is the dominant form of armed conflict in the contemporary international system (see Gleditsch et al. 2002; Melander et al. 2016). Although interstate wars have always been relatively rare, there have been very few severe interstate conflicts after the end of the Cold War, and the most severe lethal armed conflicts that have taken place over the period have all been civil rather than interstate (see Lacina and Gleditsch 2005).

Much of the academic study of civil war has traditionally been based on an assumption that intrastate conflict primarily is a domestic phenomenon, driven by features within states and with limited influence beyond the countries experiencing them. However, it is also clear from the contemporary conflict scenario that many civil wars display clear transnational characteristics, even if they may not be interstate in the sense that they involve a foreign government challenging the state (Checkel 2013). The outbreak of the civil war in Syria, for example, was clearly influenced by events in other countries, as manifested in the role that protest elsewhere during the early part of the Arab Spring played in inspiring the initial protest against the government in Syria, as well as the subsequent influence of the Libyan armed uprising in inspiring the violent insurgency and the emergence of the Free Syrian Army (Lynch 2014, 2016). Foreign intervention and external support for the fighting parties in the Syrian civil war has also been instrumental in the escalation of the conflict to become the single most severe state-based conflict event after the end of the Cold War (with an estimated 170,000 battledeaths fatalities by the end of 2015, see Melander et al 2016: 729). Finally, the events in the Syrian civil war have also lead to important humanitarian and security implications for other states. This includes, for example a large outflow of refugees to other countries in the region, concerns about 
increasing instability in neighboring countries in the region with actors linked to groups in the Syrian conflict, and the prospects for severe economic recessions in neighboring countries such as Lebanon and Jordan (Borgne 2014; Lawson 2014). The concerns of the political fallout in European countries and the spread of international terrorism also indicate that countries outside the region have not been immune to the consequences of the conflict (Bove and Böhmelt 2015; Hatton 2015). The fact that other key historical events such as the Peloponnesian war and World War emerged out of civil wars I further underscore how the transnational dimensions of civil war is not just something characteristic of the post-Cold War era, but a much more enduring phenomenon with broader relevance.

In this chapter, I will review the growth and core findings in the literature focusing on the transnational dimensions of civil war, focusing in particular on how factors outside a particular state can influence the risk of conflict within states as well as some of the central consequences of domestic conflict for other states or relations between states. In keeping with the theme of the volume my emphasis will be on the empirical and comparative literature in conflict research, and there will be some bias to the early influential studies that have shaped the research agenda rather than the details of subsequent studies. As such, I am unable to offer full justice to the many insightful theoretical and case specific studies of civil war, as well as many more neglected studies in the quantitative that merited more attention from quantitative conflict researchers. However, I hope to help provide an overview of the merits of the research agenda, and the path towards our current body of knowledge and research priorities.

\section{The growth of research on civil war}


Civil war now holds a very prominent place in quantitative conflict research, but this is in many ways a relatively recent development (Gleditsch et al. 2014). Until the end of the Cold War, the study of civil war was generally neglected in comparative conflict research. Even though initial pioneers of conflict research such as Richardson (1960) had been interested in a wide range of domestic and interstate deadly quarrels, the salience of the Cold War lead to a near exclusive primary emphasis on interstate conflict and in particular highlighted the issue of wars between the major powers. Of course, many insightful studies were conducted on individual civil wars or more specific forms of conflict processes, such as the causes of revolutions or factors affecting participation in violent rebellion (see Gurr 1970; Tilly 1978; Skocpol 1979). However, both scholars of interstate and interstate conflict tended to see these as separate domains displayed less interest in comparing their findings and enquires (although see Pillar (1983) on an insightful early discussion of differences in patterns of conflict duration and modes of termination, noting that civil wars on average lasted longer were much less likely to end in negotiated agreements.

The lack of comparative research on civil and interstate war was probably in part driven by the strong assumption that civil wars were inherently different from interstate wars. In particular, much of international relations theory insisted that the risk of interstate conflict must be seen as resulting from features of an anarchic international system, with a lack of overarching central power to enforce agreement or reduce uncertainty (Singer 1980; Waltz 1979). Although rarely stated implicitly, given that states were considered to be characterized by hierarchy rather than anarchy, it was widely assumed that the causes of wars within state must thus have different causes, failing outside the interest of traditional international relations research. Moreover, the general skepticism of any role for domestic factors such as regime type in accounting for interstate conflict tended to steer researchers 
away from investigating the possible domestic origins of intrastate conflict. Although there was some interest in examining the consequences of internal conflict for international behavior (see Rummel 1963; Wilkenfeld 1968), most of these studies did not try to account for the origins of conflict per se, but simply examine their consequences. Finally, some researchers were interested in civil wars through the concept of proxy warfare, or how superpower competition might inspire support for opposing factions in civil war, but this line of research generally tended to deemphasize local sources of conflict relative to the factors driving superpower competition (Thomas 1987). Finally, the most common data source on wars -the Correlates of War data - imposed a strict mutually exclusive classification of wars, where events could only by either civil or interstate wars, thereby downplaying the possible connection between the two types of conflict (Small and Singer 1982).

The assumption that the problem of anarchy within countries had been "effectively" solved by an effective state, establishing hierarchy, was of course always a highly questionable claim (Wagner 2007), and the perceived explosion of state failure and civil war after the end of the Cold War raised the salience of conflict within countries. Some initial research highlighted analogies between the "security dilemmas" faced by ethnic groups and an anarchic interstate system (see Posen 1993). However, this line of research was generally not quantitative, and the very direct inspiration from the somewhat atypical conflict in the breakup of the former Yugoslavia - where the central government waned in favor of titular republics controlled by ethnic group - did not extend very easily to generalizations for other civil wars. 
The quantitative study of civil war was in many ways revived and brought to prominence through the work of Paul Collier and his associates at the World Bank, focusing on the role of economic factors in civil war as well as how weak states could encourage violent challenges (Collier and Hoeffler 1998; Collier et al. 2003). The modern study of civil war drew heavily on theories of rent-seeking and collective action problems in recruiting individuals for rebellion. This differed notably from common approaches in research on interstate conflict, which typically assumed unitary actors with standing armies. However, the emphasis remained largely on the role of domestic factors in civil wars.

Studies of civil war also grew closer to research on interstate conflict following the renewed interest in how domestic factors could influence the incentives and constraints on the use of force against other states, typically associated with the concept of a liberal or democratic peace (Russett 1993). Although much of the initial research on civil war by Colliers and other political economists such as Fearon and Laitin (2003) had tended to deemphasize the role of political and economic grievances in generating conflict, subsequent studies using different measures have found more evidence that motives induced by political marginalization - whether by autocratic institutions or ethnic exclusion and discrimination - indeed are very relevant for understanding where civil wars are more likely to break out (Cederman et al. 2013; Hegre et al. 2001).

\section{The transnational causes of civil wars}

Research on civil war has grown quickly and uncovered many interesting relationships between domestic factors and propensity for civil war (Gates et al. 2006). However, over 100 years ago, Galton (1889) reminded us that apparent correlations between attributes at 
the unit level need not reflect stable structural relationship, but could also be outcomes of diffusion or dependence, where features or events in one unit subsequently influences outcomes in others. With regards to conflict, many of the domestic factors believed associated with conflict such as democracy or state strength or even aspirations of territorial independence are often strongly influenced by international factors and events elsewhere (Gleditsch 2002). For example, some argue that civil war has declined after the end of Cold War due to a spread of political and ethnic accommodation as well as improved conflict management efforts, and that these changes within countries very much reflect international forces outside individual countries (see Cederman et al. 2017; Gurr 2000)

Beyond international influences on features believed to be associated with conflict, early research on transnational influences on civil war emphasized more direct links in terms of how aspects of a state's regional environment could influence the risk of civil war over and beyond domestic features (see Gleditsch 2007; Maoz 1996). Perhaps the most direct transnational effect on the outbreak of civil war is the potential role of conflict spillovers or effects of ongoing conflict in a neighboring country. Resort to conflict is often shaped by the perceived experiences and successes of tactics used elsewhere, and an active conflict in a neighboring country can provide easier access to arms or provide logistical opportunities. For example, the rebel uprising against the white government in Rhodesia in the 1970s emulated and drew directly on the experiences of independence struggles elsewhere in Africa. More recently in Syria, the Gadaffi regime's relatively quick loss of territorial control at the outset of the Libyan uprising inspired many in Syria to think that a violent rebellion could be successful in unseating the Assad government. The importance of transnational conflict spillovers is widely acknowledged by many, and have been highlighted as a one of the few robust finding in cross-national comparative models of civil war onset (see Hegre 
and Sambanis 2006). Beyond cross-national studies, other contributions have tried to study the evidence for diffusion by identifying what states are likely to be receptive to conflict in other countries (see Black 2013; Forsberg 2014).

Beyond general spill-overs of ongoing conflicts, on other cases there are clear links between the specific actors involved in conflicts that run across national boundaries. Some groups, such as the Islamic State in Syria, have previously participated in conflict in neighboring Iraq, and they have been able to bring trained combatants and weapons captured in Iraq to the conflict in Syria. Another very important actor specific link is ethnic kinship, as many actors in conflict involve transnational ethnic communities that are present in more than one country. Gleditsch (2007) find that countries with transnational ethnic kin are more likely to see the outbreak of a civil war. Cederman et al. (2009) furthermore find some evidence that transnational kin linkages can modify the effects of purely domestic resources, in the sense that groups with transnational kin are more likely to rebel than would be expected by their local size alone. States may also be more likely to support ethnic kin in a neighboring country if they have a rivalry with the other countries (Woodwell 2004) The positive effects of transnational ethnic kin in spreading conflict between states have generally been confirmed in other studies, and has been shown to be robust to a large number of alternative estimation methods (Carmignani and Kler 2017; Bosker and Reed 2014; Forsberg 2014; Buhaug and Gleditsch 2008; Zhukov and Stewart 2013). Mobility and borders may also have other facilitating effects beyond shared ethnic ties. For example, Salehyan and Gleditsch (2006) examine ways in which an influx of refugees may increase the risk of civil war, while Salehyan (2009) argues that the ability of rebels to operate across national borders from bases in neighboring countries, in part because states face larger 
costs for efforts to retaliate against rebels across interstate boundaries, even when borders are not difficult to cross in a purely logistical sense.

One important implication of diffusion through general spill over or actor specific links is that countries can be at a higher risk of conflict in part due to factors outside their control, even if they try to pursue policies of accommodations or make efforts to reduce conflict risk. For example, although India could be seen as a democracy that has pursued largely accommodative policies to dissent, the rivalry with neighboring Pakistan appears to be an important influence sustaining violent mobilization in Kashmir. Others have noted that the 2001 Albanian uprising in Macedonia followed in the wake of efforts to provide greater accommodation and inclusion to the country's Albanian minority, which proved ineffective in curtailing the influence of previous fighters drawing inspiration from the perceived effectiveness of violent rebellion in Kosovo (Phillips 2004). Several scholars have found evidence that civil wars with outside support tend to be longer than other civil wars, which may be due to either simply extending resources to fight for an actor or the added complexity to find a solution to the conflict when the number of additional parties grows (Akcinaroglu and Radziszewski 2005; Cunningham 2010; Salehyan et al. 2011). Even peace agreements in civil wars may be difficult to sustain without cooperation from neighboring countries, but a more favorable regional environment can facilitate peace (Gleditsch 2007).

A more recent addition to this body of focuses on the non-diffusion of civil war outbreaks by highlighting how states make take countermeasures or try insulate themselves from potential spillover effects. Some highlight how certain types of states are less receptive to diffusion in the first place, for example due to higher barriers to political mobilization in states with higher capacity or greater capacity for co-opting opposition groups in ways that 
can serve as an alternative to violence (Braithwaite 2010; Maves and Braithwaite 2013). An important study by Danneman and Ritter (2014) look at the incentives of states to use preemptive efforts to quell or deter dissent in the presence of potential diffusion, and demonstrate a clear increase in state repression in the wake of dissent in neighboring states. Many researchers have noted a similar divergence in outcomes after the Arab Spring, where some of the conservatives monarchies appeared to successfully prevent a diffusion of mass-mobilization by increasing state repression of incipient dissent or introducing limited reforms (Mathiesen 2013; White et al. 2015).

\section{The transnational causes of civil wars}

In addition to research looking at how transnational factors affect the outbreak of civil war, a number of studies have looked at the transnational ramifications of civil war. Beyond effects on civil war diffusion, many studies have shown that civil war also increase the likelihood of other types of conflict, including disputes between states. Previous research on the relationship between external and internal conflict tended to see international aggression as driven by opportunistic or diversionary, with the internal conflict largely as an exogenous event (see Enterline and Gleditsch 2000; Levy 1989; Walt 1996). However, an analysis by Gleditsch, Salehyan and Schultz (2008) indicates that civil wars often generate contentious issues, which then give rise to militarized disputes or crises between states (see also Davis and Moore 1997; Moore and Davis 1998; Saideman 2001). For example, beyond supporting rebels, external states may threaten to intervene directly themselves against a government to affect the outcome of a civil war. A state experiencing civil war may try to externalize the conflict, and use force against other states to retaliate against support 
for rebels and to conduct cross-border counterinsurgency operations in other countries.

Finally, the fighting in civil wars can generate unintended security crises for other states that may give rise to interstate conflict (Salehyan 2008).

Gleditsch et al. (2008) finds that the presence of a civil war in a dyad roughly doubles the expected likelihood of a militarized interstate dispute, an effect comparable in size to the negative effect of joint democracy. Beyond the effects of civil war on the outbreaks of interstate disputes, Reeder (2014) finds that disputes that emanate out of civil wars involving direct intervention and interstate coercion are more likely to become severe, comparable to the average severity of territorial disputes. By contrast, disputes that arise from rebels operating across international borders, efforts to deter externalization and spillover events tend to have lower severity.

The domestic origins of interstate disputes can also affect the prospects for dispute settlement. Schultz (2010) argues that there are two ideal types of dyads with recurrent disputes, namely dyads with ongoing territorial disputes or claims, and dyads where repeated disputes pertain to issues over a domestic conflict and civil war. Although territorial disputes are an important source of interstate conflict and often escalate to war (Abramson and Carter forthcoming; Hensel 1996), territorial disputes are also found to be more amenable to settlement by agreement, and such settlements tend to be stable once established, since the states involved have few incentives to deviate from agreements once reached (Goertz et al. 2016). By contrast, for recurrent disputes that emanate out of civil war we also see many agreements. However, these tend to be much less effective in preventing future disputes, as they require compliance by a larger number of state actors 
only partially under the control of the states with potentially divergent interests (Carter 2015, 2016; Cunningham 2011).

A great deal of research on civil war has explored its social and economic impact, demonstrating large negative legacies in the countries experiencing them for outcomes such as economic growth and health (see, e.g., Collier et al. 2003; Gates et al. 2012; Ghobarah et al. 2004; Ghobarah et al. 2003). If civil wars have negative outcomes for the countries experiencing them, then do these then in turn also have additional negative implications for neighboring countries? A great deal of research indicate that the answer to this question often is yes, An early study by Ades and Chua (1997) found a negative impact on growth of regional instability, suggesting that conflict could interrupt trade flows with a country and lower growth through an increased defense burden. Sandler and Murdoch (2004) find a substantively large impact spill-over effect on economic growth from civil war in neighboring countries. Using a more conventional neo-classical growth model, they also consider in more detail the possible channels. Their results suggest that the effects on negative growth effects from nearby civil wars appear to arise more from the more direct implications of conflict such as uncertainty and the direct disruption of economic activity than an impact of the destruction of human or physical capital on growth. De Groot (2010) provides a reanalysis with some reservations against their interpretation, and suggests that civil wars have two distinct consequences for neighboring countries. Whereas directly contiguous countries tend to suffer from the negative effects of proximate conflict, noncontiguous countries can sometimes see positive spillover of conflict, perhaps reflecting a substitution effect. However, Dunne and Tian (2014) suggest that the negative impact also tends to be larger for secondary neighbors Bah (2013) further finds that civil war has had a negative effect on regional integration in Africa through undermining the synchronicity of 
business cycles in conflict countries and peaceful peers. The effects are particularly severe for African states since they have small domestic markets. Finally, Qureshi (2013) finds a clear negative effect of conflict on regional bilateral trade, over and beyond trade with the conflict country. In line with an increasing skepticism of cross-country regressions, more recent studies have tended to focus on impacts of individual countries, often suggesting that any effects can be very context dependent, and that even large refugee crises such as the influx of Syrians to Jordan have had relatively limited economic impacts (see, e.g., Fakih and Ibrahim 2016).

The negative consequences of civil war in other countries for security and welfare seem significantly severe so as to provide a rationale for conflict management efforts to protects countries other than the countries that see the original conflict outbreak. Collier et al. (2009) conduct a cost-benefit analysis of peacekeeping, and conclude that beyond being highly effective preventing conflict recurrent in the main country seeing conflict, peacekeeping also has clear benefits from neighboring countries Hegre et al. (2016) conduct another formal analysis of benefits for neighboring countries of different interventions in conflict countries, suggesting important transnational effects.

\section{Transnational conflict}

I noted in the introduction that traditional research often tended to draw a sharp separation between interstate and intrastate conflict, in some cases insisting that conflicts must be classified as one type or the other. Although there are many real differences between states and non-state actors, it is also clear from the contemporary global conflict that many conflicts do not fit neatly into civil or interstate war as ideal types. For example, the 2001 US 
intervention against the Taliban regime in Afghanistan clearly generated an interstate conflict. However, the previous civil war and fighting between different armed parties in the country clearly did not disappear with the US intervention, and the conflict had previously had strong international dimensions through the Soviet intervention in support for the government and the US support for the Mujahedeen insurgents, who also attracted large numbers of foreign fights and recruited from Afghan refugees in Pakistan. An alternative to traditional binary distinctions is to approach individual conflicts as broader clusters that may fall somewhere along a spectrum from clearly domestic civil war to clearly international conflict, and may include a complex set of transnational interactions between non-state and state actors in multiple countries. International intervention and transnational actors and alliances are for example a prominent feature of many current conflicts such as Syria and Yemen.

Moreover, going beyond the conventional dichotomy and taking a comparative approach to a wider range of conflict also helps focus on learning more about explanations of conflict and interesting variation across types (Cunningham and Lemke 2015). Many have noted that research on civil war over the last decades has been much more cumulative than previous research on interstate conflict. Perhaps learning rates are simply increasing exponentially with time and more comprehensive data. Still, my own personally view is that we have learned fundamental things about issues in interstate conflict and the prospects for agreement and conflict management by looking at comparisons with interstate conflict, and that this has been a productive shift over the emphasis in traditional IR theory on military capabilities detached from preferences and largely time-invariant structural factors. Likewise, a focus on transnational factors and linkages have also helped generate progress in propositions to explain civil wars, both by raising important challenges to traditional 
closed polity approaches to civil war, as well as pointing to important distinct influences on civil war dynamics and outcomes. Although many individual claims may remain contentious and there may be a great deal of ambiguities over interpretations of findings and the relevant causal mechanisms, there can be little doubt that the interest in transnational factors has enriched the study of civil war, and will remain central in future research. 


\section{References}

Abramson, Scott F, and David B. Carter. forthcoming. "The Historical Origins of Territorial Disputes." American Political Science Review:in press.

Ades, Alberto, and Hak B. Chua. 1997. "Thy Neighbor's Curse: Regional Instability and Economic Growth." Journal of Economic Growth 2 (3):279-304.

Akcinaroglu, Seden, and Elizabeth Radziszewski. 2005. "Expectations, Rivalries, and Civil War Duration." International Interactions 31 (4):349-74.

Bah, Adama. 2013. "Civil Conflicts as a Constraint to Regional Economic Integration in Africa." Defence and Peace Economics 24 (6):521-34.

Black, Nathan. 2013. "When Have Violent Civil Conflicts Spread? Introducing a Dataset of Substate Conflict Contagion." Journal of Peace Research 50 (6):751-9.

Borgne, Eric Le. 2014. "Lebanon: Economic and Social Impact of the Syrian Conflict." Washington, DC: Wold Bank.

Bosker, Maarten, and Joppe de Reed. 2014. "Ethnicity and the spread of civil war." Journal of Development Economics 108:206-21.

Bove, Vincenzo, and Tobias Böhmelt. 2015. "Does Immigration Induce Terrorism?" Journal of Politics 78 (2):572-88.

Braithwaite, Alex. 2010. "Resisting Infection: How State Capacity Conditions Conflict Contagion." Journal of Peace Research 47 (3):311-9.

Buhaug, Halvard, and Kristian Skrede Gleditsch. 2008. "Contagion or Confusion? Why Conflicts Cluster in Space." International Studies Quarterly 52 (2):215-33.

Carmignani, Fabrizio, and Parvinder Kler. 2017. "The spillover of war in time and space: exploring some open issues." Applied Economics 49 (3):273-88.

Carter, David. 2015. "The Compellence Dilemma: International Disputes with Violent Groups." Intrnational Studies Quarterly 59 (3):461-76.

- - . 2016. "Provocation and the Strategy of Terrorist and Guerilla Attacks." International Organization 70 (1):133-73.

Cederman, Lars-Erik, Kristian Skrede Gleditsch, and Halvard Buhaug. 2013. Grievances and Inequality in Civil Wars. Cambridge and New York: Cambridge University Press.

Cederman, Lars-Erik, Kristian Skrede Gleditsch, and Luc Girardin. 2009. "Ethnic Triads: Assessing the Influence of Kin Groups on Civil Wars." World Politics 61 (3):403-37.

Cederman, Lars-Erik, Kristian Skrede Gleditschy, and Julian Wucherpfennig. 2017. "Predicting the Decline of Ethnic Civil War: Was Gurr Right and For the Right Reasons?" Journal of Peace Research:in press.

Checkel, Jeffrey T., ed. 2013. Transnational Dynamics of Civil War. Cambridge: Cambridge University Press.

Collier, Paul, Lisa Chauvet, and Haavard Hegre. 2009. "The Challenge of Conflicts." In Global Crises, Global Solutions: Second Edition, ed. B. Lomborg. Cambridge: Cambridge University Press.

Collier, Paul, Lani Elliott, Håvard Hegre, Anke Hoeffler, Marta Reynal-Querol, and Nicholas Sambanis. 2003. Breaking the Conflict Trap: Civil War and Development Policy: Oxford University Press and Washington, DC: World Bank, online at http://econ.worldbank.org/prr/CivilWarPRR/.

Collier, Paul, and Anke Hoeffler. 1998. "On Economic Causes of Civil War." Oxford Economic Papers 50 (4):563-73.

Cunningham, David. 2010. "Blocking Resolution: How External States can Prolong Civil Wars." Journal of Peace Research 47 (2):115-27.

Cunningham, David E. 2011. Barriers to Peace in Civil War. New York: Cambridge University Press. 
Cunningham, David E., and Douglas Lemke. 2015. "Combining Civil and Interstate Wars " International Organization 67 (3):609-27.

Danneman, Nathan, and Emily Ritter. 2014. "Contagious Rebellion and Preemptive Repression." Journal of Conflict Resolution 58 (2):254-79.

Davis, David R., and Will H. Moore. 1997. "Ethnicity Matters: Transnational Ethnic Alliances and Foreign Policy Behavior." International Studies Quarterly 41 (1):171-84.

De Groot, Olaf J. . 2010. "The Spillover Effects of Conflict on Economic Growth in Neighboring Countries in Africa." Defence and Peace Economics 21 (2):149-64.

Dunne, J. Paul, and Nan Tian. 2014. "Conflict Spillovers and Growth in Africa." Peace Economics, Peace Science and Public Policy 20 (4):539-49.

Enterline, Andrew J., and Kristian S. Gleditsch. 2000. "Threats, Opportunity, and Force: Externalization of Domestic Pressure, 1946-82." International Interactions 26 (1):21-53.

Fakih, Ali, and May Ibrahim. 2016. "The impact of Syrian refugees on the labor market in neighboring countries: empirical evidence from Jordan." Defence and Peace Economics 27 (1):64-86.

Fearon, James D., and David D. Laitin. 2003. "Ethnicity, Insurgency, and Civil War." American Political Science Review 97 (1):75-90.

Forsberg, Erika. 2014. "Diffusion in the Study of Civil Wars: A Cautionary Tale." International Studies Review 16 (2):188-98

Galton, Francis. 1889. "Comment on E.B. Tylor 'On a Method of Investigating the Development of Institutions: Applied to Laws of Marriage and Descent'." Journal of the Royal Anthropological Institute 18:268-9.

Gates, Scott, Håvard Hegre, Mark P. Jones, and Håvard Strand. 2006. "Institutional Inconsistency and Political Instability: Polity Duration, 1800-2000." American Journal of Political Science 50 (4):893-908.

Gates, Scott, Håvard Hegre, Håvard Mokleiv Nygård, and Håvard Strand. 2012. "Development Consequences of Armed Conflict." World Development 40 (9):1713-22.

Ghobarah, Hazem Adam, Paul Huth, and Bruce Russett. 2004. "The Postwar Public Health Effects of Civil Conflict." Social Science and Medicine 59 (4):869-84.

Ghobarah, Hazem Adam, Paul Huth, and Bruce M. Russett. 2003. "Civil Wars Kill and Maim PeopleLong after the Shooting Stops." American Political Science Review 97 (2):189-202.

Gleditsch, Kristian Skrede. 2002. All International Politics is Local: The Diffusion of Conflict, Integration, and Democratization. Ann Arbor, MI: University of Michigan Press.

- - . 2007. "Transnational Dimensions of Civil War." Journal of Peace Research 44 (3):293-309.

Gleditsch, Nils Petter, Jonas Nordkvelle, and Håvard Strand. 2014. "Peace research - Just the study of war?" Journal of Peace Research 51 (2):145-58.

Gleditsch, Nils Petter, Peter Wallensteen, Mikael Eriksson, Margareta Sollenberg, and Håvard Strand. 2002. "Armed Conflict 1946-2001: A New Dataset." Journal of Peace Research 39 (5):615-37.

Goertz, Gary, Paul F. Diehl, and Alexandru Balas. 2016. The Puzzle of Peace: The Evolution of Peace in the International System. New York: Oxford University Press.

Gurr, Ted R. 1970. Why Men Rebel. Princeton, NJ: Princeton University Press.

Gurr, Ted Robert. 2000. "Ethnic Warfare on the Wane." Foreign Affairs 79 (3):52-64.

Hatton, Timothy J. 2015. "Refugees and Asylum Seekers, the Crisis in Europe and the Future of Policy." Centre for Economic Policy Research Discussion Paper No. DP11271.

Hegre, Håvard, Halvard Buhaug, Katherine V Calvin, Jonas Nordkvelle, Stephanie T Waldhoff, and Elisabeth Gilmore. 2016. "Forecasting civil conflict along the shared socioeconomic pathways." Environmental Research Letters 11 (5):054002.

Hegre, Håvard, Tanja Ellingsen, Scott Gates, and Nils Petter Gleditsch. 2001. "Toward a Democratic Civil Peace? Democracy, Political Change, and Civil War, 1816-1992." American Political Science Review 95:33-48.

Hegre, Håvard, and Nicholas Sambanis. 2006. "Sensitivity Analysis of Empirical Results on the Causes of Civil War Onset." Journal of Conflict Resolution 50 (4):508-35. 
Hensel, Paul R. 1996. "Charting a Course to Conflict: Territorial Issues and Interstate Conflict." Conflict Management and Peace Science 15 (1):43-74.

Lacina, Bethany, and Nils Petter Gleditsch. 2005. "Monitoring Trends in Global Combat: A New Dataset of Battle Deaths." European Journal of Population Studies 21 (2-3):145-66.

Lawson, Fred. 2014. "Syria's mutating civil war and its impact on Turkey, Iraq and Iran." International Affairs 90:1351-65.

Levy, Jack S. 1989. "The Diversionary Theory of War: A Critique." In Handbook of War Studies, ed. M. I. Midlarsky. Ann Arbor, MI: University of Michigan Press.

Lynch, Marc. 2016. The New Arab Wars: Uprisings and Anarchy in the Middle East. New York: PublicAffairs.

- - , ed. 2014. The Arab Uprisings Explained: New Contentious Politics in the Middle East. New York: Columbia University Press.

Maoz, Zeev. 1996. Domestic Sources of Global Change. Ann Arbor, MI: University of Michigan Press.

Mathiesen, Toby. 2013. Sectarian Gulf: Bahrain, Saudi Arabia, and the Arab Spring That Wasn't. Stanford, CA: Stanford University Press.

Maves, Jessica, and Alex Braithwaite. 2013. "Autocratic Institutions and Civil Conflict Contagion." Journal of Politics 75 (2):478-90.

Melander, Erik, Therése Pettersson, and Lotta Themnér. 2016. "Organized violence, 1989-2015. ." Journal of Peace Research 53 (5):727-42

Moore, Will H., and David R. Davis. 1998. "Ties that Bind? Domestic and International Conflict Behavior in Zaire." Comparative Political Studies 31 (1):45-71.

Phillips, John. 2004. Macedonia: Warlords and Rebels in the Balkans. New Haven, CT: Yale University Press.

Pillar, Paul R. 1983. Negotiating Peace: War Termination as a Bargaining Process. Princeton, NJ: Princeton University Press.

Posen, Barry R. 1993. "The Security Dilemma and Ethnic Conflict." Survival 35 (1):27-47.

Qureshi, Mahvash Saeed. 2013. "Trade and thy neighbor's war " Journal of Development Economics 105:178-95.

Reeder, Bryce W. 2014. "Civil war and the severity of militarized interstate disputes." Research \& Politics 1 (3):https://doi.org/10.1177/2053168014556403.

Richardson, Lewis F. 1960. Statistics of Deadly Quarrels. Chicago, Pittsburgh, PA: Quadrangle/Boxwood.

Rummel, Rudolph J. 1963. "Dimensions of Conflict Behavior Within and Between Nations." General Systems 8:1:50.

Russett, Bruce M. 1993. Grasping the Democratic Peace: Principles for the Post Cold War World. Princeton, NJ: Princeton University Press.

Saideman, Stephen M. 2001. The Ties That Divide: Ethnic Politics, Foreign Policy, and International Conflict. New York: Columbia University Press.

Salehyan, Idean. 2008. "The Externalities of Civil Strife: Refugees as a Source of International Conflict." American Journal of Political Science 52 (4): 787-801

-- - 2009. Rebels Without Borders: State Boundaries, Transnational Opposition, and Civil Conflict. Ithaca, NY: Cornell University Press.

Salehyan, Idean, and Kristian Skrede Gleditsch. 2006. "Refugee Flows and the Spread of Civil War." International Organization 60 (2):335-66.

Salehyan, Idean, Kristian Skrede Gleditsch, and David E. Cunningham. 2011. "Explaining External Support for Insurgent Groups." International Organization 65 (4):709-44.

Sandler, Todd, and James Murdoch. 2004. "Civil War and Economic Growth: Spatial Dispersion." American Journal of Political Science 48 (1):138-51.

Schultz, Kenneth A. 2010. "The Enforcement Problem in Coercive Bargaining: Interstate Conflict over Rebel Support in Civil Wars." International Organization 64 (2):281-312 
Singer, J. David, ed. 1980. The Correlates of War II: Testing Some Realpolitik Models. New York: Free Press.

Skocpol, Theda. 1979. States and Social Revolutions: A Comparative Analysis of France, Russia and China. New York: Cambridge.

Small, Melvin, and J. David Singer. 1982. Resort to Arms: International and Civil Wars, 1816-1980. Beverly Hills, CA: Sage.

Thomas, Caroline. 1987. "The Superpowers and the Third World." Review of International Studies 13 (3):235-42.

Tilly, Charles. 1978. From Mobilization to Revolution. Reading, MA: Addison-Wesley.

Wagner, R. Harrison. 2007. War and the State: The Theory of International Politics. Ann Arbor, MI: University of Michigan Press.

Walt, Stephen. 1996. Revolution and War. Ithaca, NY: Cornell University Press.

Waltz, Kenneth N. 1979. Theory of International Politics. Reading, MA: Addison-Wesley.

White, Peter, Dragana Vidovic, Belen Gonzalez, Kristian Skrede Gleditsch, and David Cunningham. 2015. "Nonviolence as a Weapon of the Resourceful: From Claims to Tactics in Mobilization " Mobilization: An International Journal 20 (4):471-91.

Wilkenfeld, Jonathan. 1968. "Domestic and Foreign Conflict Behavior of Nations." Journal of Peace Research 5:56-69.

Woodwell, Doug. 2004. "Unwelcome Neighbors: Shared Ethnicity and International Conflict during the Cold War." International Studies Quarterly 48 (1):197-223.

Zhukov, Yuri M., and Brandon M. Stewart. 2013. "Choosing Your Neighbors: Networks of Diffusion in International Relations." International Studies Quarterly 57 (2):271-87. 